\title{
Samhällsvårdade barn, gate-keeping och forskning
}

\section{MARIE SALLNÄS, STEFAN WIKLUND \& HÉLÈNE LAGERLÖF}

\author{
Ett aktörsperspektiv på barn har blivit alltmer centralt $i$ \\ barn- och barnavårdsforskning. I artikeln diskuteras prin- \\ cipiella och praktiska frågor när ett sådant perspektiv ska \\ omsättas i forskning om samhällsvårdade barns förhållan- \\ den. Avvägningen mellan forskningsintresset och barns \\ rätt till skydd och integritet analyseras.
}

\section{Inledning}

Hur har barn det i Sverige? Den frågan ställs ofta i undersökningar och svaren väcker stort intresse (Jonsson et al. 2001, Ungdomsstyrelsen 2007, 2008). Forskningen och dess resultat har dock sällan rört barn som via socialtjänstens försorg är placerade i familjehem eller vid institution/ HVB (hem för vård eller boende). En given dag befinner sig nästan 16000 barn i någon sådan vårdmiljö. Vi vet påfallande lite om hur dessa barn från sin horisont uppfattar tillvaron eller hur de ser på socialtjänstens

Marie Sallnäs, professor, Institutionen för socialt arbete, Stockholms universitet

Stefan Wiklund, universitetslektor, Institutionen för socialt arbete, Stockholms universitet

Hélène Lagerlöf, doktorand, Institutionen för socialt arbete, Stockholms universitet ambitioner att hjälpa dem eller föra dem till rätta. I den mån samhällsvården är studerad är det i huvudsak via vuxnas ögon och ofta utifrån socialtjänstens perspektiv. Detta trots att man i barn- och barnavårdsforskning allt oftare hänvisar till det barndomssociologiska synsättet där en nyckeltes är att betrakta barn som »sociala aktörer" och därmed som individer med både rätt och kompetens att komma till tals (James \& Prout 1997, James, Jenks \& Prout 1998, se också Kampmann 2003).

Att se barn som aktörer innebär bl.a. att utgå från att de både kan och vill påverka den sociala värld de lever i och att de är förmögna att fatta självständiga beslut (i olika grad beroende på ålder). I forskning bör ett sådant perspektiv leda till ett ökat intresse för unga som självständiga och betydelsefulla informanter. Att omsätta en 
sådan tanke i praktisk handling aktualiserar emellertid en rad principiella, metodologiska och praktiska frågor (se Christensen \& James, 2008) som har återverkningar på sådant som bortfall och i förlängningen forskningens genomförbarhet. I studier som rör barn i samhällsvård är detta särskilt accentuerat. Runt barn i familjehem och HVB finns ett antal gate-keepers, dvs. personer med eller utan organisatorisk anknytning till vårdmiljöerna, som har möjlighet att försvåra eller hindra forskare att få access till de unga.

En gate-keeper kan släppa in eller stänga ute. Gate-keeping runt barn måste finnas och man kan säga att föräldraskap innebär ett självklart inslag av gate-keeping. För barn i samhällsvård finns emellertid en utökad skara av möjliga gate-keepers som kan inta olika positioner på skalan släppa in-stänga ute. Det finns idag ingen systematisk kunskap om gate-keeping/gate-opening i forskningssammanhang som rör barn i svensk samhällsvård.

Christensen och Prout (2002) efterlyser en diskussion inom forskarkollektivet om metodmässiga och etiska frågor i relation till ett aktörsperspektiv på barn (se också Hopkins \& Bell 2008). Vi har tagit fasta på den uppmaningen. Syftet med artikeln är att diskutera gate-keeping runt barn i samhällsvård och forskningsmässiga implikationer av sådan gate-keeping. Vi vill belysa avvägningen mellan å ena sidan möjligheten att som forskare ge samhällsvårdade unga reella chanser att komma till tals om sina förhållanden och å andra sidan barns rätt till skydd, integritet och privat livsutrymme. Vi ger en praktisk belysning utifrån en studie av levnadsnivå bland unga i familjehem och institutioner (Sallnäs et al, 2010). Den diskussion vi för ser vi i många stycken som principiellt relevant för barnoch ungdomsforskning i stort, men i synnerhet för forskning om unga som i någon mening kan betraktas som "utsatta" och för vars räkning en utökad krets av vuxna kan agera (jfr. Källström Cater \& Överlien 2008). Följande frågeställningar behandlas:

1. Hur och av vem utövas gate-keeping runt samhällsvårdade barn i forskningssammanhang?

2. Hur kan man som forskare förhålla sig till vuxnas gate-keeping i relation till barns egen vilja?

3. Vilka konsekvenser har gate-keeping för forskningens resultat och genomförbarhet samt i ett vidare perspektiv för kunskapsproduktionen om samhällsvårdade barn?

Det finns flera kategorier av vuxna aktörer som är intressanta att diskutera i relation till ovanstående frågeställningar men vi har här lagt tyngdpunkten på de vuxna i vårdmiljöerna, dvs. familjehemsföräldrar och personal vid institutionerna (HVB). Dessa personer har ingen formell beslutanderätt över de ungas deltagande i forskning men har stort inflytande över deras tillvaro.

I den studie vi hämtat erfarenheter ifrån och som vi refererar till i denna artikel, ville vi undersöka tillgången till välfärdsresurser för barn i familjehem och HVB samt analysera skillnader gentemot jämnåriga som bor med sina ursprungsfamiljer. Vi ställde motsvarande frågor till samhällsvårdade unga 13-18 år ( $\mathrm{n}=272)$ som man $\mathrm{i}$ de nationella levnadsnivåundersökningarna 
ställt till barn som bor med föräldrarna (Jonsson et al. 2001). Frågorna berörde exempelvis de ungas fritid, skola, kamratkontakter samt ekonomiska och materiella resurser. Barnen fick i hörlurar lyssna på en röst som läste upp frågor och de angav sina svar i ett formulär med i huvudsak fasta svarsalternativ (samma metod har använts i de nationella levnadsnivåundersökningar som inkluderar barn).

\section{Begränsadforskning om barns uppfattningar}

Trots barndomssociologins sedan mer än tio år starka teoretiska position i barnavårdsforskningen är den i praktiken genomförda forskningen med unga som informanter relativt mager både i Sverige och internationellt - inte minst $\mathrm{i}$ fråga om studier med större undersökningsgrupper (Berrick et al. 2000, se också Egelund \& Hestbaek 2003, Kendrick et al. 2008). Holland (2009) menar dock att tendensen är att placerade barns erfarenheter och perspektiv $i$ allt större utsträckning faktiskt finns med i forskningen, men att det råder brist på diskussioner om de etiska frågor som uppkommer när barn är informanter.

I svensk forskning har däremot andra grupper av utsatta barn, exempelvis de som bevittnat våld $\mathrm{i}$ hemmet eller är involverade i familjerättsprocesser, varit informanter i olika studier och man har där diskuterat etiska dilemman i relation till synen på barn som aktörer kontra deras behov av skydd och omsorg (Eriksson \& Näsman 2007, 2008, 2009; Källström Cater \& Överlien 2008).
Större studier med systematiska jämförelser mellan samhällsvårdade och hemmaboende barn har tidigare inte gjorts i Sverige. Förhållandena för placerade barn har i första hand synliggjorts i djupgående studier med små undersökningsgrupper. Det främsta svenska exemplet är Gunvor Anderssons unika longitudinella studie, där författaren vid upprepade tillfällen intervjuat en grupp personer $(n=26)$ som blev placerade i samhällsvård som små barn (se t.ex. Andersson 2005, 2008; se också Andersson 1998). I övrigt har främst ungdomar vid de av staten drivna särskilda ungdomshemmen framträtt i forskningen, både via intervjuer och observationer och ofta $\mathrm{i}$ kombination med intervjuer av personalen (se t.ex. Degner \& Henriksen, 2007; Överlien, 2004). I Danmark pågår emellertid en stor longitudinell studie av barn födda 1995 (n=943) som placerats i samhällsvård. I den andra delrapporten intervjuas barnen när de hunnit bli 11 år (förutom flera kategorier av vuxna) (Egelund et al. 2004, 2008). Studien visar mycket tydligt på klyftan mellan samhällsvårdade barn och deras jämnåriga liksom på den problemtyngd som finns hos föräldrarna och hos många av barnen i familjehem och vid institutioner.

\section{Barn i en vuxenstyrd värld}

Innebörder och implikationer av tesen om barn som "sociala aktörer" är långt ifrån självklara, vare sig för forskningen eller för praktikfältet inom socialt arbete. Aktörstanken understryker snarast det dilemma som ligger i att barn skall komma till tals, samtidigt som de är djupt bero- 
ende av vuxna och vuxnas agerande. Att tillskriva barn aktörskap innebär att en komplex uppsättning av relationer till vuxna (t.ex. föräldrar, lärare, myndighetsrepresentanter eller som i vår studie forskare, familjehemsföräldrar och institutionspersonal) måste relateras till barns specifika intressen. Flera forskare pekar på att det i samhället finns en tvetydig inställning till ett mera förpliktigande perspektiv på barn som aktiva individer och att deras aktörskap i realiteten ofta diskvalificeras (se t.ex. Egelund \& Hestbaek 2003, Eriksson \& McLeod 2006, Näsman 2007, 2008, Sandbaek 2004a).

\section{Gate-keeping och gate-opening}

Gate-keeping ("att vakta grinden") kan beskrivas som en process som reglerar gruppers eller individers tillgång till eller exkludering från arenor eller resurser. För barn i samhällsvård kan gate-keepern vara en person i vårdmiljön eller en förälder som rättmätigt hjälper en ung person att skydda sig mot en mer eller mindre hotande omvärld. Men gate-keeping kan också innebära överbeskydd, att vuxna för talan för barn som mycket väl själva kan uttrycka sin mening (Thomas \& O'Kane 1998, Winter 2006, se också Morrow \& Richards 1996). I allvarliga fall kan gatekeeping handla om direkt förtryck eller maktmissbruk.

Att vakta grinden kan också innebära att öppna den, dvs. gate-opening (Curtis et al. 2004). De vuxna i samhällsvården kan naturligtvis även ha en sådan roll. Det kan vara problematiskt om en gate-opener är så entusiastisk att forskningsdeltagande framstår som något närmast obligatoriskt. Barnavårdsinstitutioner har beskrivits med uttrycket »a goldfish bowl" (ett akvarium) för att understryka att barn som befinner sig i en institutionell miljö kan vara särskilt synliga och åtkomliga (Kendrick et al. 2008, s. 84). Det finns studier inom medicinsk forskning där placerade barn använts på ett oetiskt sätt för att de varit lätt tillgängliga och saknat vuxna som skyddat dem.

\section{Att involvera barn iforskning - huvudsakligen pro- argument}

Det har framför allt i utländsk litteratur förts en diskussion om varför barn bör involveras i forskning och under vilka former. Man hittar sällan argument mot ungas forskningsmedverkan, däremot olika uppfattningar om i vilken grad barn bör medverka. Diskussionen kan grovt sammanfattas på följande sätt.

- $\quad$ Barns uppfattningar kan ges mer eller mindre tyngd: "participation" respektive "consultation". Det första begreppet innebär att föra aktörsperspektivet till sin spets. Utöver att barn har rollen som informanter skall de också engageras i uppläggningen av studier, liksom i tolkningen av data. Consultation kan beskrivas med termen "seeking views» och står för en mer återhållsam linje ifråga om barns forskningsmedverkan (Hill et al. 2004, Sime 2008). 
- Barn i samhällsvård (eller som är föremål för andra samhällsinsatser) har viktiga erfarenheter som bara de kan förmedla och som kan addera viktig kunskap till forskningen och i förlängningen till sociala myndigheter. De ungas uppfattning bör också ses ur ett demokrati- och medborgarrättsperspektiv och kopplas till de rättigheter för barn att komma till tals som anges i FN's barnkonvention och för Sveriges del även i Socialtjänstlagen (Gilligan 2000, MacNaugthon et al. 2007).

- När samhällsvården i stor utsträckning är privatiserad, är barn inte i den positionen att de kan sända signaler på marknaden för att på det viset signalera missnöje/tillfredställelse med vården (Cortis 2007). Dagens svenska institutionsvård drivs till mycket stor del av privata företag som säljer vårddygn till socialtjänsten (se Sallnäs 2005), vilket understryker vikten av att på andra sätt än via marknadssignaler ta reda på hur barn har det $\mathrm{i}$ sina vårdmiljöer.

- Ett av de få argument som problematiserar aktörstesen är motsättningen mellan barns rätt att bli hörda och deras rätt att bli beskyddade. En alltför stark betoning av barns kompetens kan innebära att de hamnar i situationer de rimligen inte kan ta ansvar för, såväl i forskningssammanhang som i övrigt (Andersson \& Swärd 2008, Gustavsson, 2006, Sandbaek 2004a).

\section{Barns medgivande}

Om barn (liksom vuxna) skall kunna ta ställning till deltagande i en studie är det underlag de har för sitt beslut naturligtvis viktigt. Kendrick et al. (2008 s. 86) menar att den information som ges bör innehålla upplysningar om "who, what, when och how" (se också Backett-Milburn et al. 2003, Redmond 2008). Det bör också göras tydligt att forskningsprojektet inte kan påverka de ungas direkta situation även om de är missnöjda. Inom medicinen gör man en distinktion mellan terapeutisk forskning som kan vara direkt nyttig för deltagaren och icke-terapeutisk forskning där detta inte är fallet. I huvudsak måste social barnavårdsforskning - och samhällsvetenskaplig forskning i stort - ses som icketerapeutisk.

Barns ålder är centralt i förhållande till frågan om medgivande. Ett långt drivet aktörsperspektiv tillskriver också mycket små barn en relativt omfattande kompetens och beslutsförmåga. När det gäller unga i "mellanåldern", ca 10-13 år, kan man anta att kompetens och beslutsförmåga gradvis erövras, vilket delvis är en funktion av vilket utrymme vuxna i närmiljön ger. Detta gäller i princip också för tonåringar, men det är troligare att de generellt kan betraktas som mer självständiga gentemot vuxna, även om vuxnas agerande också för denna åldersgrupp spelar en stor roll. I Sverige bedöms 15 år vara en rimlig gräns för självständigt ställningstagande (oavsett vårdnadshavarens uppfattning) när det gäller forskningsmedverkan. Om barn under 15 år inte vill delta, skall forskningen inte genomföras även om vårdnadshavaren 
samtycker. Yngre barn kan alltså självständigt besluta att avstå, men inte att delta.

Flera författare pekar på medgivande som en förhandlingsprocess med ett stort antal aktörer, och som också när det kommer till barnen själva måste ses som pågående. De unga kan ändra sig och måste få tydlig information om att det är möjligt. Kendrick et al. (2008) skiljer mellan medgivande (consent) och tillåtelse (permission) och menar att socialarbetare och andra företrädare för barn kan ge tillåtelse men inte medgivande. Det senare kan bara ges av de unga själva och skall hela tiden vara möjligt att dra tillbaka, "ongoing consent" (se också Källström Cater \& Överlien 2008).

Sammanfattningsvis kan man konstatera att tesen om barn som aktörer innebär att ytterligare dimensioner läggs till det redan komplicerade förhållandet mellan barns autonomi och vuxnas makt. Hur vuxnas tillåtelse (permission) eller om man så vill gate-opening respektive barns medgivande (consent) förhåller sig till varandra är centralt i den fortsatta framställningen. I Figur 1 illustreras översiktligt tänkbara kombinationer av barns inställning till att delta $i$ forskning i relation till vuxnas gate-keeping och hur "utfallet» av de olika kombinationerna kan ses.

I övre rutan till vänster är barnen »aktörer", de vill delta i forskning och får möjlighet att göra det. I övre rutan till höger är de unga också positiva till att delta, men stark gate-keeping förekommer, vilket kan ses som att barnen blir inkompetensförklarade och överbeskyddade. I den nedre rutan till vänster är barnen ovilliga att delta men de vuxna reser inga hinder för tillträde (de kanske t.o.m. agerar gate-openers) vilket gör att barnen inte kan skydda sig. Om forskare inte uppfattar eller bryr sig om signaler om att de unga inte vill vara med, kan barnen ses som "forskningsoffer". I undre

\section{Figur I.}

Barns inställning till att delta i forskning i relation till gate-keeping.

Positiva till deltagande

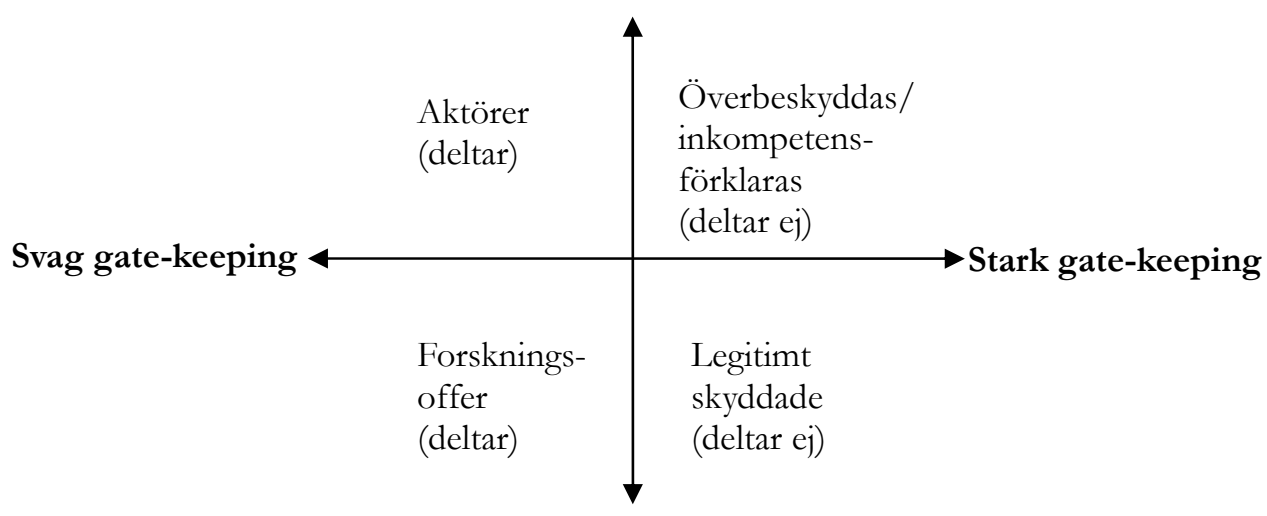

Negativa till deltagande 
rutan till höger slutligen är barnen negativa till att delta och de stöds i detta av sin omgivning, de blir med andra ord legitimt skyddade.

De fyra kategorierna blir med nödvändighet förenklingar och modellen bygger på att de unga har en egen inställning som kan artikuleras i någon form. Längre fram i texten skall vi diskutera erfarenheterna från vår studie i relation till modellens kategorier.

\section{Gate-keeping i praktiken - samhällsvårdade barns vilja och skyddande aktörer}

Innan vi närmare går in på vår studie av levnadsnivå bland unga i pågående samhällsvård skall något sägas om denna undersökningsgrupp. Vid studiens genomförande befinner sig barnen i socialtjänstens dygnsvård (sedan minst sex månader). De har placerats på grund av förhållandena i hemmet eller på grund av sitt eget beteende. Vi kan utgå från att merparten av barnen kommer från biologiska familjer med en problematisk välfärdsposition. Tidigare forskning om barn i samhällsvård visar en kraftig överrepresentation av barn till föräldrar som är lågutbildade, har långvarigt ekonomiskt bistånd och är ensamstående (Socialstyrelsen 2006, Egelund et al. 2008). Vi kan alltså utgå från att barnen i vår studie stött på svårigheter av olika slag och kanske sviktar många av dem i sitt förtroende för vuxna och för samhället i stort, vare sig det representeras av socialtjänsten eller forskare.

\section{Levnadsnivåundersökning}

I den levnadsnivåstudie från vilken vi hämtat de erfarenheter som diskuteras i den här artikeln är barn (13-18 år) huvudinformanter. Från början hade vi för avsikt att ta med också 10-12-åringar, men svårigheterna att nå dem visade sig så stora att de fick uteslutas ur undersökningen (se längre fram i texten under rubriken Ålderns betydelse). De vuxna i vårdmiljöerna ombads besvara en enkät som i huvudsak rörde rena faktauppgifter. I övrigt har vi sett deras svar som komplement till de ungas.

Med levnadsnivåbegreppet beskriver man människors liv i termer av vilka resurser de har tillgång till och vilka möjligheter de därmed har att handla inom olika områden (Jonsson et al. 2001). Bland välfärdsindikatorerna ingår exempelvis politiska resurser och inflytande samt delaktighet när beslut skall fattas. Själva levnadsnivåbegreppet kan alltså sägas innefatta en aktörsdimension (se Eriksson \& Näsman 2007). En viktig tanke är att samma resurser som är viktiga för vuxna också är betydelsefulla för barn, men resurserna tas i anspråk inom olika arenor. Välfärdsfrågor och barn i samhällsvård behandlas ofta i diskursivt åtskilda forskningsfält, men i den här studien kopplas fälten samman.

Ända fram till 2000-talet var det enbart vuxnas välfärd som undersöktes i de nationella levnadsnivåundersökningarna. Barns välfärdsresurser undersöktes via föräldrarna. Det är först under senare år som barn har ingått som självständiga respondenter, vilket kan ses som ett uttryck för aktörsperspektivets frammarsch i synen på barn. 
Välfärdsmätningarna har inkluderat endast en mycket liten grupp unga i familjehem, och inte några av dem som är placerade i HVB. Barn i familjehem och institutioner kan i det här avseendet betraktas som en "hidden population" (Lambert \& Wiebel 1990), trots att man kan se det som särskilt angeläget att ha kunskap om levnadsnivå för just denna grupp eftersom samhället så påtagligt trätt in i deras liv.

\section{En kedja avgate-keepers}

Barn i samhällsvård har en speciell position i den meningen att de dels - liksom alla barn - är underställda vuxna, dels är beroende av socialtjänstens agerande. De unga befinner sig i denna mening $i$ en dubbel beroendesituation. En placering i samhällsvård innebär att HVB-personal eller familjehemsföräldrar tar över åtminstone delar av de uppgifter som för andra unga åligger föräldrarna, vilket innebär flera möjliga gate-keepers/gate-openers. Mängden personer som kan ha uppfattningar om de ungas väl och ve är större än för andra barn. I brittisk forskning talar man om "korporativt föräldraskap« (Leeson 2007). Begreppet syftar på en allmän skyldighet för olika samhällsrepresentanter som kommer i kontakt med samhällsvårdade barn att ta tillvara barnens intressen.

Förutsättningen för att vår studie skulle kunna genomföras var att vi fick tillträde till de barn vars uppfattning vi ville ta del av och att barnen kunde och var villiga att svara på våra frågor. I vårt fall skulle först en etisk kommitté pröva om studien var i enlighet med forskningsetiska principer, sedan skulle socialtjänsten besluta om att lämna ut uppgifter om vilka barn som var placerade. Därefter behövdes i praktiken medverkan från familjehemsföräldrar och HVB-personal, även om dessa inte äger frågan om barns medgivande (consent) $\mathrm{i}$ formell mening. Det krävdes också att vårdnadshavare till de barn som var under 15 år gav sitt tillstånd. Här kan nämnas att det är oklart om deltagande i forskning är en fråga som kräver två vårdnadshavares samtycke, eller om det räcker med en av dem (vi nöjde oss med en vårdnadshavares samtycke). Först efter att vi tagit oss förbi kedjan av potentiella gate-keepers kunde barnen nås. Man har i brittisk forskning talat om wa hierarchy of gatekeeping" som löper från en organisatorisk nivå över föräldrar till barn (Kendrick et al. 2008, se också Leeson 2007). Det är svårt att invända mot var och en av dessa skyddande lager runt samhällsvårdade barn, men tillsammans innebär de påtagliga svårigheter och mycket tidsåtgång i forskningssammanhang.

\section{Frågan om bortfall}

Bortfall är bekymmersamt därför att man kan befara att de personer som inte deltar i en studie skiljer sig från de som är med, vilket innebär risk för snedvridning av resultat. Sandbaek (2004b) menar att man måste vänta sig bortfallsnivåer på 40-60 procent när forskningen rör grupper som det är svårt att nå fram till. Författarens egen studie av barn i norska låginkomstfamiljer redovisar ett bortfall om 47 procent. Också andra studier illustrerar problemet. Ungdomsstyrelsens undersökning av 
attityder bland unga har ett bortfall på 43 procent (Ungdomsstyrelsen 2003, se också Ungdomsstyrelsen 2005). I en studie av barn till narkotikamissbrukare där forskaren tog direktkontakt via brev med föräldrar och barn var svårigheterna att få fram 18 barn (från en grupp om 67 föräldrar) betydande (Claezon 1996). När man i en svensk studie av 10-åringar vände sig till barnen via skolan var emellertid andelen icke-svarande så låg som tolv procent (Andersson \& Linge 1997).

Bekymret med bortfall gäller givetvis också unga i samhällsvård. Det finns en risk att problem i populationen underskattas, därför att de som har det sämst eller mår sämst i högst utsträckning finns i bortfallet. I den tidigare nämnda danska longitudinella studien av barn i samhällsvård var bortfallet vid intervjuer med 11-åringar påfallande stort. Man fick avstå från att intervjua så många som 82 procent av barnen, men fick in data från andra källor (socialsekreterare och vårdmiljöer) vilket ledde till att man hade uppgifter från någon källa för 64 procent av barnen (Egelund et al. 2008). Man fann dock att det inte var någon skillnad mellan de samhällsvårdade barn som deltog och de som inte gjorde, det när det gällde variabler som moderns utbildning, inkomst och förekomst av psykiatrisk diagnos. I en brittisk studie av barn i familjehem var bortfallet 40 procent (Sinclair et al. 2001). I vissa andra studier av samhällsvårdade barn har bortfallet varit ett mindre problem, exempelvis $i$ det omfattande Barn-i-krisprojektet (se t.ex. Cederström 1990, Lindén 1998) som genomfördes på 1980-talet och omfattade samtliga barn under 16 år som placerades av Malmö kommun ( $\mathrm{n}=86)$ under ett och ett halvt år. En sannolik förklaring är att kommunens personal från början var involverad i projektet. Också i Gunvor Anderssons longitudinella studie av barn i samhällsvård är bortfallet mycket lågt, vilket rimligen hänger samman med att författaren som barnhemspsykolog etablerade kontakt med barnen (och deras föräldrar) i tidig ålder (Andersson 2008). I samma författares studie av 22 barn i familjehem uppgick bortfallet till 29 procent (Andersson 1998).

Den nationella levnadsnivåundersökning som vi hämtat våra jämförelsedata från hade ett bortfall om 24 procent bland de vuxna vars barn man intervjuat (Jonsson et al. 2001). Bland de hemmavarande barn som ingick i studien var bortfallet lågt, 15 procent, i jämförelse med andra studier. I den nationella studien var bortfallet emellertid av en annan karaktär än i vår. Det var i ett första led de vuxna i familjerna som inte ville delta, vilket innebar att också deras barn föll bort. Först i nästa steg, när föräldrarna ingick i vuxenstudien, tillfrågades barnen. Bland de få barn i familjehem som kom med i urvalet var bortfallet 45 procent. Det skall tilläggas att man i den nationella levnadsnivåstudien hade med barn i åldern 10-12 år, en grupp som vi var tvungna att utesluta.

Även om bortfallet i den nationella levnadsnivåstudien var högre för vissa grupper (t.ex. barn i ombildade familjer och till utrikes födda föräldrar, barn med olika former av funktionsnedsättningar) bedömer författarna att bortfallet knappast snedvrider resultatet. Man menar dock att barn "vars vardagsverklighet skulle behöva 
bli representerad i den totala bilden över de ungas levnadsförhållanden« i högre uträckning var förhindrade att delta i undersökningen och att detta är ett problem i sig (Jonsson et al. 2001, s. 58). Också i denna studie stötte man på viss gate-keeping som kunde avläsas i ett samband mellan lågt deltagande bland barnen och att de vuxna i familjerna inte ville delta eller ge tillstånd till barnens deltagande. Att en negativ inställning från vuxna smittar av sig på barnen skulle kunna tolkas som en form av "psykologisk gate-keeping". Vuxnas och barns vilja är i dessa sammanhang sannolikt tätt hopflätade med varandra, och det kan vara så att barnen hade ställt sig annorlunda om de varit omgivna av andra vuxna. Frågan om de ungas vilja blir i detta sammanhang således mycket komplex.

I vår studie hade vi vid datainsamlingens slut fått in ifyllda svarsformulär från 272 barn medan 162 personer inte deltog i studien, vilket ger ett bortfall på 37 procent. Bland unga i $\mathrm{HVB}$ var bortfallet lägre, 31 procent, än bland de i familjehem, 44 procent. Skillnaden är sannolikt delvis ett uttryck för att vi oftare lyckades komma i kontakt med HVB-hemmen. Det hänger rimligtvis samman med att ett HVB i allmänhet är "öppet« $i$ den meningen att någon finns där som man kan tala med. För att nå familjehemmen tillkom problem i form av felaktiga adressuppgifter.

Vi lade ner stora ansträngningar på att få ner bortfallet. Det innebar bl.a. att vi skickade flera brev med förfrågan om deltagande och information om undersökningen. Vi tog också telefonkontakt med vårdmiljöer där unga fanns som vi inte hade fått svar från och med barnen själva om de var 15 år eller äldre, när det var möjligt. Utan detta arbete hade vi haft ett betydligt svagare empiriskt underlag i studien. Vår bedömning är att de insatser vi gjorde för att få ner bortfallet ledde till att svarsfrekvensen blev relativt god om man jämför med andra studier där barn är respondenter, vare sig de är i samhällsvård eller inte. Problemet kvarstår dock att vi inte vet $\mathrm{i}$ vilken mån de unga som inte deltog i studien var föremål för legitimt skydd eller för överbeskydd/ inkompetensförklaring och vi kan inte heller vara säkra på hur det påverkar resultaten.

\section{Alderns betydelse}

Att barns kompetens bedöms utifrån deras ålder får betraktas som mer eller mindre självklart. Det innebär att skyddsaspekten måste väga tyngre för yngre barn. Andersson och Swärd (2008) intervjuade inledningsvis små barn (4-5 år) i en studie om hemlösa familjer, men kom fram till att det inte var rätt att utsätta barnen för frågor som handlade om ett liv dessa barn inte hade tillgång till. I vår studie var det, som nämnts, så svårt att komma i kontakt med de 10-12-åringar som ursprungligen ingick i vår undersökningsgrupp att vi beslöt exkludera dem. Vanliga motiveringar från de vuxna i vårdmiljöerna var att barnen var för sårbara, sköra eller inte skulle förstå. I andra fall var det vårdnadshavare som vi inte kunde komma i kontakt med eller som inte samtyckte. I den tidigare nämnda danska studien (Egelunds et al. 2008) var detta ett stort problem och en viktig förklaring till det höga bortfallet för 11-åring- 
arna. Bägge studierna pekar på stark gatekeeping runt barn i 11-12 årsåldern och man kan tentativt resa frågan i vilken mån erfarenheter bland samhällsvårdade barn i dessa åldrar över huvud taget är forskningsbara i större studier. Det är en rimlig tolkning att samhällsvården är en kontext som innebär särskilda hinder, även om man har lyckats nå yngre barn i studier med mindre undersökningsgrupper (se Andersson 1998, 2005, 2008).

\section{Bortfallsorsaker-empiriska exempel frän vår studie}

Det vanligaste skälet till bortfall i vår studie var att familjehemsföräldrar eller HVB-personal för de ungas räkning meddelade att han/hon inte ville delta: "Vi har pratat med $x$ som säger att han/hon inte vill vara med" eller "x har läst brevet och kom och sa att han/hon inte har tid just nu«. Denna typ av avböjande låg bakom nästan hälften av bortfallet. En mindre grupp unga meddelade själva (genom att fylla i svarstalong, via telefon eller sms) att de inte ville vara med. Dessa två kategorier av bortfall betraktade vi som relativt oproblematiska och vill placera i rutan benämnd legitimt skydd i Figur 1, även om vi inte kan vara helt säkra på att de vuxna som framförde de ungas avböjande verkligen hade frågat dem.

Som principiellt mest diskutabel kan man betrakta den kategori, där vuxna i vårdmiljöerna mer eller mindre tydligt bestämde att barnen inte skulle delta. Familjehemsföräldrar eller HVB-personal meddelade att barnen inte skulle vara med i studien, men det framgick inte vilken inställning de unga själva hade. I några fall hade man från de vuxnas sida tagit hand om det till barnet adresserade brevet, men utan att vidarebefordra det. Man ansåg att den unge inte skulle tillfrågas över huvud taget och formulerade det i termer av skydd, t.ex. att han/hon hade en besvärlig situation vid just detta tillfälle, hade så många kontakter med folk som ville ställa frågor (t.ex. socialsekreterare) eller hade för låg begåvning för att klara intervjun. En HVB- föreståndare uppgav att inget av de barn som var berörda var intresserade av att "vara försökskanin«. Vårt intryck var att föreståndaren var negativ till idén och att det kan ha påverkat de unga - om de över huvud taget hade tillfrågats. Kanske fanns här inslag av det vi tidigare kallat psykologisk gate-keeping, dvs. att det är svårt att särskilja barns vilja från vuxnas (jfr Jonsson et al. 2001). Generellt kan man tala om det vi i Figur 1 kallar överbeskydd och inkompetensförklaring.

Förhållandena kunde också vara omvända. Vi stötte på både familjehemsföräldrar och HVB-personal (och biologiska föräldrar) som var mycket positiva till studien, vilket kan ha påverkat de unga till att delta. Här kanske man kan tala om psykologisk gate-opening. Bland vuxna som kan påverka barn i deras beslut kan man i princip också inkludera forskare som vill ha access till unga. Hopkins (2008) pekar på risken att låtsas erbjuda ett val, medan den egentliga förväntan och förhoppningen från forskarens sida är att barnen utan trassel skall delta och svara på frågorna. Vuxna i vårdmiljöerna kan, i allians med ivriga forskare som vill få ner bortfallet, utgöra en 
stark press på barn att delta, vilket kan göra dem till forskningsoffer. Även om medgivande i princip inte bör betraktas som slutgiltigt och de unga $i$ vår studie informerades om att de när som helst kunde avbryta intervjun (ongoing concent), kan det inte uteslutas att situationen uppfattades som mer eller mindre tvingande.

\section{Barns inställning-hurfår man reda på vad de vill?}

Som framgått kunde den gate-keeping som utövades runt barnen göra det svårt att beakta deras vilja. Borde vi som forskare ha försökt gå förbi gate-keepers i form av HVB-personal eller familjehemsföräldrar för att klargöra de ungas inställning? Även om aktörsperspektivet och dess demokratiaspekt skulle tala för det, fann vi det inte rimligt. Rent praktiskt hade vi förmodligen kunnat få direktkontakt med en del unga i främst familjehemmen via deras mobiltelefoner eller genom att ringa till familjehemmen på eftermiddagarna när barn ofta är hemma, men sällan de vuxna. Vi avstod dock från detta. Det förelåg en uppenbar risk att de unga skulle känna sig pressade och därigenom hamna i en potentiell konfliktsituation med vuxna i vårdmiljöerna. Naturligtvis måste man också ha i åtanke att de vuxnas agerande kunde handla om legitimt skydd, med andra ord att de unga inte skulle fara väl av ett deltagande. Detta illustrerar dilemmat mellan att se barn som sociala aktörer och i linje med det göra dem till informanter om sina liv och det beskydd vuxna kan, vill och bör ge dem. Vi kan inte annat än lite lakoniskt instämma med Cree et al. (2002): utan samarbete med gate-keepers - ingen forskning.

\section{Summering och diskussion}

\section{Gate-keeping,gate-opening och bortfall}

När man som utomstående forskare vill komma i kontakt med barn i samhällsvård blir maktrelationerna unga lever i tydliga. För att komma till tals med de unga måste man ta sig förbi en kedja av instanser och personer. Vuxna i olika positioner kan påtagligt begränsa eller till och med hindra barns deltagande i forskning, men de kan också underlätta det. Vi har stött på bägge delarna, men vi vet inte säkert hur vuxnas inställning har balanserats mot de ungas vilja. Vi har inte funnit tydliga tecken på att barn blivit forskningsoffer (för lite gatekeeping). Vi har däremot stött på det vi uppfattat som överbeskydd och inkompetensförklaring (för mycket gate-keeping), men också vuxna som, så vitt vi kunnat bedöma, legitimt skyddat barn.

Vår konklusion är att även en så svårtillgänglig grupp som barn i samhällsvård kan nås i forskningssyfte, också i studier med större undersökningsgrupper. Reservationer måste dock göras för barn i lägre åldrar, en grupp som vi inte lyckades nå och som man i tidigare forskning enbart vänt sig till i mindre kvalitativa studier.

Vi har också kunnat konstatera att det går att få acceptabla bortfallsnivåer i större studier av samhällsvårdade unga. Bortfallet på 37 procent är ungefär i nivå med (eller t.o.m. något lägre än) vad som rapporte- 
rats från studier av andra grupper av unga, vilket får betraktas som ett gott resultat med tanke på den kontext barnen i vår studie befinner sig i. Svårigheterna med att få ned bortfallet bör dock poängteras och när projekt av den här typen planeras måste tid och möda för att hantera gate-keeping tas med i beräkningen.

\section{Barns vilja}

Även om ambitionen är att barn själva skall ta ställning till forskningsdeltagande, måste man utgå från att deras uppfattning i hög grad påverkas av och medieras via de vuxna de har omkring sig. Men kan man dra slutsatsen att det var fler unga som ville delta i vår undersökning än vad som faktiskt gjorde det? Man kan inte svara med ett enkelt ja eller ett nej på den frågan. Det förefaller rimligare att se barns vilja utifrån en axel med grader av villighet som i olika mån påverkas av och måste relateras till de vuxnas inställning (vilket vi illustrerat i Figur 1). Synsättet gäller i princip för såväl barn i samhällsvård som för barn som bor med föräldrarna. I det första fallet är det av samhället utsedda representanter som parallellt med föräldrarna är "de vuxna" och som i den egenskapen har stort inflytande genom att kunna öppna eller stänga möjligheten för forskare att komma i kontakt med de unga. Vi kan inte säkert veta i vilken utsträckning de barn som inte medverkade i studien kan ses som legitimt skyddade eller som överbeskyddade och inkompetensförklarade. Vi kan dock vara säkra på att bortfallssiffror i en undersökning som vår inte kan ses som en enkel avspegling av de ungas egen inställning till att delta

Om bortfallets storlek representerar den andel barn som faktiskt inte vill delta, är det något man som forskare får finna sig i och hantera på bästa sätt. Om den istället betyder att unga genom gate-keeping fråntagits sin möjlighet att medverka är det inte bara ett forskningsmetodologiskt bekymmer, utan också ett vidare problem utifrån ett medborgar- och demokratiperspektiv. Att gå så långt som att undanhålla brev med fråga om de unga vill delta $\mathrm{i}$ forskning måste ses som ett tydligt uttryck för inkompetens-/överbeskyddspositionen. De vuxna argumenterade utifrån de ungas situation och hävdade "det bästa för barnen«. Som sådana kan argumenten naturligtvis ha rimlighet $\mathrm{i}$ de enskilda fallen och innebära legitimt skydd. Problem uppstår emellertid om man betraktar samhällsvårdade barn som en universell kategori som i denna egenskap saknar kompetens och beslutsförmåga. Barn i samhällsvård är olika och vissa är mer aktörsinriktade och aktiva än andra. Det problematiska är om de som grupp antas vara inkompetenta, därför att de befinner sig i samhällsvård.

\section{Konsekvenserförforskning och kunskapsproduktion}

Både gate-keeping och gate-opening runt barn måste hanteras varsamt, inte minst när unga i samhällsvård är berörda. Barnavårdsinstitutioner och familjehem skall inte vara inrättningar där barn studeras för att de är lätt åtkomliga och saknar skydd av biologiska föräldrar eller andra vuxna. Men 
det är inte heller rimligt att barn avskärs från möjligheter att själva bestämma om kontakter med utomstående, t.ex. med forskare för att därigenom bidra till kunskapen om hur det är att befinna sig i samhällsvård. Hur denna balans hanteras och bör hanteras är långt ifrån självklart, men har betydande konsekvenser för barnavårdsforskningen.

De kunskapsluckor som finns när det gäller barns upplevelser av samhällsvård kan, i Sverige liksom i andra länder, åtminstone delvis kopplas till svårigheter att genomföra forskning med unga som informanter (Backett-Milbrun et al. 2003, Redmond 2008). Om detta leder till att man avstår från att genomföra forskning innebär det att vissa grupper av unga inte får sina förhållanden belysta. Det faktum att barn är samhällsvårdade och därmed har en dubbel beroendeställning till vuxenvärlden (dels till sina föräldrar, dels till familjehemsföräldrar/HVB-personal och i förlängningen socialtjänstens personal), kan till och med ses som ett argument för att det är extra viktigt att forska om deras villkor och att göra det utifrån ett aktörsperspektiv. Just det dubbla beroendet kan vara ett starkt skäl att värna deras möjlighet att framföra sin uppfattning. Det ligger en paradox $i$ att ambitioner att skydda barn kan få till konsekvens att de unga hindras från att vara aktörer. Skelton (2008) uttrycker det som att makten läggs i händerna på dem som redan tidigare har social makt över barn.

Berrick et al. (2000) skriver "the challenge of conducting research with children in foster care are formidable». Vi kan inte annat än instämma i detta. Men även om svårigheterna är stora är det, som samma författare påpekar, särskilt viktigt att fråga dem som är berörda när ett system genomgår stora förändringar (a.a.). Det gäller för den amerikanska samhällsvården författarna har undersökt och det gäller i hög grad för svensk samhällsvård. Under de senaste decennierna har vi sett en ökning av antalet placeringar av unga, en kraftig privatisering av institutionsvården med åtföljande omstruktureringar samt en tendens mot professionalisering av delar av familjehemsvården (Sallnäs 2009). Vi vet lite om konsekvenserna av detta och saknar också kunskap om hur berörda barn uppfattar nya (och gamla) miljöer som finns i det svenska vårdlandskapet. Precis som för andra barn, behövs kunskap om samhällsvårdade barns upplevelser och förhållanden - enligt deras egen uppfattning. Sådan forskning är viktig, men den måste utföras med medvetna avvägningar mellan å ena sidan forskningsmässiga ambitioner och å andra sidan barns intressen och rätt till integritet. 


\section{Referenser}

Andersson, G. (1998) "Föräldrakontakt och familjetillhörighet ur fosterbarns perspektiv«. Socialvetenskaplig Tidskrift, vol. 5, nr 1, s. 3-23.

Andersson, G. (2005) „Family relations, adjustment and well-being in a longitudinal study of children in care». Child and Family Social Work, vol. 10, s. 43-56.

Andersson, G. (2008) Utsatt barndom - olika vuxenliv. Stockholm: Allmänna Barnhuset.

Andersson, G. \& Linge, L. (1997) Tioåringars kompetens och levnadsförhållanden. Meddelanden från Socialhögskolan, 13. Lund: Lunds universitet, Socialhögskolan.

Andersson, G. \& Swärd, H. (2008) „Etiska reflektioner». I A. Meeuwisse, H. Swärd, R. EliassonLappalainen \& K. Jacobsson (red.) Forskningsmetodik för socialvetare. Stockholm: Natur \& Kultur

Backett-Milburn, K., Cunningham-Burley, S. \& Davis, J. (2003) "Contrasting lives, contrasting views? understanding of health inequalities from children in different circumstances", Social Science \& Medicin, vol. 57, s. 613-623.

Berrick, Duerr J., Frach K. \& Fox, A. (2000) "Assessing children's experiences of out-ofhome care. Methodological challenges and opportunities", Social Work Research, vol. 24, nr 2, s. 119-127.

Cederström, A. (1990) Fosterbarns anpassning - en relationsproblematik. Stockholm: Stockholms universitet, Pedagogiska institutionen.

Christensen, P. \& Prout, A. (2002) „Working with Ethical Symmetry in Social Research with Children", Childhood, vol. 9, nr 4, s. 477-497.

Christensen, P. \& James, A. (2008) Research with Children. Perspectives and Practices. London: Routledge.

Claezon, I. (1996) Mot alla odds. Barn till narkotikamissbrukare berättar om sin uppväxt. Stockholm: Mareld.

Cortis, N. (2007) "What do service users think of evaluation? Evidence from family support", Child and Family Social Work, vol. 12, nr 4, s.
399-410

Cree, V., Kay H. \& Tisdall K. (2002) „Research with children: sharing the dilemmas", Child and Family Social Work, vol. 7, s. 47-56.

Curtis K., Roberts H., Copperman J., Downie A. \& Liabo K. (2004) "'How come I don't get asked no questions?' Researching 'hard to reach' children and teenagers", Child and Family Social Work, vol. 9, s. 167-175.

Degner, J. \& Henriksen, A. (2007) Placerad utanför sitt sammanhang. En uppföljningsstudie av 46 institutionsplacerade ungdomars privata och formella relationer. Örebro: Institutionen för beteende-, social- och rättsvetenskap, Örebro universitet.

Egelund, T. \& Hestbeak, A-D. (2003) Anbringelse af børn og unge uden for hjemmet. En forskningsöversigt. Köpenhamn: Socialforskningsinstituttet.

Egelund T., Hestbæk A-D. \& Andersen D. (2004) Små børn anbragt uden for hjemmet: En forløbsundersøgelse af anbragte børn født $i 1995$. Köpenhamn: Socialforskningsinstituttet.

Egelund T., Andersen D., Hestbaek A-D., Lausten M., Knudsen L., Fugelsang Olsen R. \& Gerstoft, F. (2008) Anbragte børns udvikling og vilkair. Resultater fra SFI's forløbsundersøkelse af årgång 1995. Köpenhamn: SFI/Det nationale forskningscenter for velfaerd.

Eriksson, M. \& Näsman, E. (2007) „Delaktighet i familjerättsprocesser för barn som upplevt pappas våld mot mamma", Socionomens forskningssupplement, 22, s. 78-89.

Eriksson, M. \& Näsman, E. (2008) „Intervjuer och barns delaktighet». I M. Eriksson, Å. Källström Cater, G. Dahlkild-Öman \& E. Näsman (red.) Barns röster om våld. Malmö: Gleerups.

Eriksson, M. \& Näsman, E. (2009) „Utsatta barn i familjerättsprocesser: utredarens bemötande och barns strategier", Socialvetenskaplig Tidskrift, vol. 16, nr 1, s. 20-37.

Gilligan, R. (2000) »The importance of listening to the child in foster care». I G. Kelly \& R. Gilligan 
(red.) Issues in Foster Care: Policy, Practice and Research. London: Jessica Kingsley Publishers.

Gustafsson, K. (2006) Vi och dom i skola och stadsdel. Barns identitetsarbete och sociala geografier. Uppsala: Pedagogiska institutionen, Uppsala universitet.

Hill, M., Davis, J., Prout, A. \& Tisdall, K. (2004) "Moving the Participation Agenda Forward", Children \& Society, vol. 18, nr 2, s. 77-96.

Holland, S. (2009) "Listening to Children in Care. A Review of Methodological and Theoretical Approaches and Understanding Looked after Children's Perspectives", Children \& Society vol. 23, nr 3, s. 226-235.

Hopkins, P. (2008) „Ethical issues in research with unaccompanied asylum-seeking children", Children's Geographies, vol 6, nr 1, s. 37-48.

Hopkins, P \& Bell, N (2008) »Interdisciplinary perspectives: ethical issues and child research", Children's Geographies, vol 6, nr 1, s. 1-6.

James, A. \& Prout, A. (1997) Constructing and Reconstructing Childhood. London: Falmer Press.

James, A. Jenks, C. \& Prout, A. (1998) Theorizing Childhood. Cambridge: Polity Press.

Jonsson J., Östberg, V., Evertsson, M. \& Brolin Loftman, S. (2001) Barns och ungdomars välfärd. SOU 2001:55. Stockholm.

Kampmann, J. (2003) "Barndomssociologi - fra marginaliseret provokatør till mainstream leverandør", Dansk sociologi, vol. 14, nr 2, s. 79-93.

Kendrick A., Steckely L. \& Lerpiniere J. (2008) "Ethical issues, research and vulnerability: gaining the views of children and young people in residential care", Children's Geographies, vol. 6, nr 1, s. 79-93.

Källström Cater, Å. (2004) Negotiating normality and deviation - father's violence against mother from children's perspectives. Ak för Juridik, psykologi och socialt arbete. Örebro: Örebro universitet.

Källström Cater, Å. \& Överlien, C. (2008) „Etiska dilemman i tolkande forskning med barn som upplevt våld». I M. Eriksson, Å. Källström Cater, G. Dahlkild-Öman \& E. Näsman (red.) Barns röster om våld. Malmö: Gleerups.
Lambert, E .\& Wiebel, W. (1990) "Identifying and Gaining Access to Hidden Populations». I E. Lambert (red.) The Collection and Interpretation of Data from Hidden Populations. NIDA Research Monograph 98. Rockville: National Institute on Drug Abuse.

Leeson, C. (2007) »My life in care: experiences of non-participation in decision-making process", Child and Family Social Work, vol. 12, nr 3 s. 268-277.

Lindén, G. (1998) Att bli fosterbarn i tonåren. Om frigörelsen från internaliserade föräldraobjekt. Stockholm: Almqvist \& Wiksell.

MacNaugthon, G., Hughes, P. \& Smith, K. (2007) "Young Children's Rigths and Public Policy. Practices and Possibilities for Citizenship in the Early Years", Children \& Society, vol 21, s. 458-469.

McLeod, A.(2006) »Respect or empowerment? Alternative understandings of 'listening' in childcare social work", Adoption \& Fostering, vol. 30, nr 3, s. 43-52.

Morrow, V. \& Richards, M. (1996) »The Ethics of Social Research with Children: An Overview", Children \& Society, vol. 10, nr 2, s. 90-105.

Redmond, G. (2008) Childrens' perspectives on economic adversity: a review of the literature. Sydney: University of South Wales, The Social Policy Research Centre.

Sallnäs, M. (2005) „Vårdmarknad med svårigheter - om privata aktörer inom institutionsvården för barn och ungdomar", Socialvetenskaplig Tidskrift, vol. 12, nr 2-3, s. 226-245.

Sallnäs, M. (2009) "Swedish Residential Care in the Landscape of Out-of-home care". In Residential Care of Children: Comparative Perspectives. Oxford: Oxford University press.

Sallnäs, M., Wiklund, S. \& Lagerlöf, H. (2010) "Social barnavård ur ett välfärdsperspektiv. Ekonomiska och materiella resurser, psykisk hälsa och tillgång till socialt stöd för ungdomar i familjehem och institutioner", Socialvetenskaplig Tidskrift, vol 17, nr1, s. 5-27.

Sandbaek, M. (2004a) »Barn i hjelpeapparetet kompetente og sårbare aktører", Nordisk Sosialt Arbeid, vol. 2, nr 24, s. 98-109. 
Sandbaek, M. (2004b) „Barn i inntektsfattige familier". I M. Sandbaek (red.) Barns levekår. Hva betyr familiens inntekt? Nova Rapport 1 1/2004. Oslo: Norsk institutt for forskning om oppvekst, velferd og aldring.

Sime, D. (2008) „Ethical and methodological issues in engaging young people living in poverty with participatory research methods", Children's Geographies, vol. 6, nr 1, s. 63-78.

Sinclair, I., Wilson, K. \& Gibbs, I. (2001) „'A life more ordinary' What children want from foster placements", Adoption \& Fostering, vol. 25, nr 4, s. 17-26.

Skelton, T. (2008) „Research with children and young people: exploring the tensions between ethics, competence and participation", Children's Geographies, vol. 6, nr 1, s. 21-36.

Socialstyrelsen (2006) Social rapport. Stockholm: Socialstyrelsen.

Thomas, N. \& O'Kane, C. (1998) »The Ethics of Participatory Research with Children", Children \& Society, 12, s. 336-348.
Ungdomsstyrelsen (2003) De kallar oss unga. Ungdomsstyrelsens attityd- och värderingsstudie 2003. Stockholm: Ungdomsstyrelsen.

Ungdomsstyrelsen (2005) Arenor för alla - en studie om ungas kultur- och fritidsvanor. Stockholm: Ungdomsstyrelsen.

Ungdomsstyrelsen (2007) Fokus 2007. En analys av ungas hälsa och utsatthet. Stockholm: Ungdomsstyrelsen..

Ungdomsstyrelsen (2008) Ung idag. En beskrivning av ungdomars villkor. Stockholm: Ungdomsstyrelsen.

Winter, K. (2006) »Widening our knowledge concerning young looked after children: the case for research using sociological models of childhood", Child and Family Social Work, vol. 11, s. 55-64.

Överlien, C. (2004) Girls on the verge of exploding? Voices on sexual abuse, agency and sexuality at a youth detention home. Linköping: Linköpings universitet.

\section{Summary}

\section{Children in out-of-home care, gate-keeping and research}

Within the discourse of childhood sociology, children are extensively regarded as "social actors", a perspective that underlines the importance of asking children about their lives and experiences. To actually carry out such research, however, raises several methodological, theoretical, ethical and practical issues, especially when the research is about vulnerable children like those in out-of-home care. In this article we discuss the issue of gate-keeping when conducting research with children in foster homes or residential care. As a concrete example we use experiences from a survey of living conditions among those children. The research questions were: 1) How and by whom is gate-keeping carried out when research is conducted among children in out-of-home care? 2) How could one as a researcher relate to gate-keeping carried out by adults in the environment of the children against the children's own will? 3) What impact does gate-keeping have on results, feasibility and in a wider perspective the production of knowledge regarding children in social care? The article shows 
that researchers need to encounter a chain of gate-keepers to be able to get access to the children, and often attrition is high in studies with children as informants. Adults can serve both as gate-keepers and gateopeners. Our conclusion is that children in social care can be reached for research purposes, but that it is time-consuming, challenging and as a researcher one is often faced with ethical dilemmas. It is clear that there has to be a balance between gatekeeping and gate-opening. In this balance, on the one hand, it is possible for children to talk to researchers when they wish to do so, on the other hand, children must be protected so they are not exploited as research objects. 